\title{
Interrelationship for yield and yield associated traits in mustard (Brassica juncea L.)
}

\author{
Piar Ali Shar ${ }^{1 *}$, Jay Kumar Sootaher ${ }^{1}$, Zahoor Ahmed Soomro ${ }^{1}$,
} Tanweer Fatah Abro ${ }^{1}$, Akhtar Hussain Shar ${ }^{2}$, Muhammad Saleem Chang $^{3}$, Ayaz Ali Soomro ${ }^{4}$, Nadir Ali Rind ${ }^{2}$ and Khalid Hussain Rind $^{2}$

1. Department of Plant Breeding and Genetics, Sindh Agriculture University, Tandojam, Sindh-Pakistan

2. Department of Molecular Biology and Genetics, Shaheed Benazir Bhutto University, Shaheed Benazirabad, Sindh-Pakistan

3. Department of Agronomy, Subcampus Umerkot, Sindh Agriculture University, Tandojam, Sindh-Pakistan

4. Department of Plant Breeding and Genetics, Subcampus Umerkot, Sindh Agriculture University, Tandojam, Sindh-Pakistan

*Corresponding author's email: drpiaralishar@gmail.com

Citation

Piar Ali Shar, Jay Kumar Sootaher, Zahoor Ahmed Soomro, Tanweer Fatah Abro, Akhtar Hussain Shar, Muhammad Saleem Chang, Ayaz Ali Soomro, Nadir Ali Rind and Khalid Hussain Rind. Interrelationship for yield and yield associated traits in mustard (Brassica juncea L.). Pure and Applied Biology. Vol. 9, Issue 3, pp1988-1994. http://dx.doi.org/10.19045/bspab.2020.90212

\begin{tabular}{|c|c|c|c|}
\hline Received: 17/02/2020 & Revised: 05/05/2020 & Accepted: 03/06/2020 & Online First: $15 / 06 / 2020$ \\
\hline
\end{tabular}

\section{Abstact}

The association among yield and affecting traits were analyzed for nine yield contributing traits at Oilseeds Section, ARI, Tandojam in randomized complete block design with three replications during 2018-2019. The analysis of variance revealed that all genotypes were highly significant at 0.01 probability level for all the attributes. BJD BARD-1 maintained the minimum days to $75 \%$ flowering (47.42 days), AARI Canola produced minimum days to $90 \%$ maturity (120.20 days) and maximum branches plant ${ }^{-1}$ (9.46) along with maximum seeds pod ${ }^{-}$ ${ }^{1}$ (17.22), Super Raya exhibited the shortest plants $(182.39 \mathrm{~cm})$, maximum pods plant $^{-1}(482.57)$ and seed yield plant ${ }^{-1}(30.44 \mathrm{~g})$, while Dhoom-1 articulated the maximum seed index (6.48 g) and JS-13 demonstrated the most oil content (39.28\%). It was identified positive as well as highly significant linkage between seed yield plant ${ }^{-1}$ and days to $75 \%$ flowering $\left(0.6556^{* *}\right)$, between seed yield plant ${ }^{-1}$ and days to $90 \%$ maturity $\left(0.7271^{* *}\right)$, between seed yield plant ${ }^{-1}$ and branches plant $^{-1}(0.4762 * *)$ and between seed yield plant-1 and pods plant ${ }^{-1}(0.8498 * *)$. Whereas, significant and positive associations were found between seed yield plant ${ }^{-1}$ and plant height $(0.4562 *)$ and between seed yield plant ${ }^{-1}$ and seeds $\operatorname{pod}^{-1}\left(0.3433^{*}\right)$. It was finalized, positive correlation indicated that selection of these attributes demonstrating significant results would be very fruitful and progressive for desirable genes. The better performed mustard genotypes will be able to be utilized in future for mustard development programmes to improve yield associated characters.

Keywords: Interrelationship; Mustard; Yield; Yield associated traits

\section{Introduction}

Mustard (Brassica juncea L.) comes from the family so called Brassicaceae. It is also said to be Indian mustard. The crop is a perennial herb, but almost grown as an 
annual or biennial. Central Asia is thought to be the primary center of origin for mustard, however the secondary centres are central and western China [1]. The species and cultivars of this genus are these days under agriculture in the form of forage as well as feed crops in most of the parts of the world [2].

Pakistan is an agro based economic country in which consumption and production differentiate immensely and this space is advancing year after year [3]. Edible oil production in our country is not fulfilling the want because of its growing demand with swift rising inhabitants [4].

Genetic analysis plays a very good role in the breeding of such crops in which correlation is extremely fruitful for the improvement and progress of hybrid mustard seed production. Connection is extremely effective when path coefficient analysis is brought under the process as it splits the direct and indirect effects in yield and its linked traits [5]. When there is an adequate large magnitude of changeability in the breeding population, the choice functions very well [6]. The nature and amount of inconsistency in the existing material and linkage among numerous morphological attributes is a prerequisite for any breeding programme to be begun by the home-grown breeders for high produces [7].

Yield is not so easy as researchers regard, it is helped by many other traits. The components partaking encouraging correlation with yield can be used in the indirect selection for yield and entertains a substitute for yield betterment. A proper evaluation of vital crop species assists in the identification and utilization of improved genotypes [8]. The current investigation was consequently commenced for fitting selection principles for green mustard genotypes through the study of interrelationship between yield and its components.

\section{Materials and methods}

The breeding material was composed of ten genotypes mustard, namely AARI Canola,
JS-13, BJD BARD-1, BJD Khanpur Raya, Early Raya, Sindh Raya, MS-4, Anmol Raya, Dhoom-1 and Super Raya. The observations were recorded on days to $75 \%$ flowering, days to $90 \%$ maturity, plant height $(\mathrm{cm})$, branches plant ${ }^{-1}$, pods plant ${ }^{-1}$, seeds pod $^{-1}$, seed yield plant ${ }^{-1}(\mathrm{~g})$, seed index (g) and oil content (\%) to estimate the interrelationship in the genotypes of mustard for yield and yield contributing characters. The experiment was conducted during the Rabi season of 2018-2019 at Botanical Garden, Department of Plant Breeding and Genetics, Sindh Agriculture University, Tandojam using ten genotypes in randomized complete block design with three replications. The plant to plant and row to row space was maintained at $30 \mathrm{~cm}$ and $75 \mathrm{~cm}$, respectively.

\section{Statistical analysis}

Analysis of variance was applied to the data according to the method suggested by [9], the means were compared using Least Significant Difference with assistance of the method of [10]. and correlation was estimated developed by [11].

\section{Results and discussion Analysis of variance}

An aim of any plant breeding program is to progress high yielding varieties with better quality superior over existing one. The ANOVA of mustard genotypes presented in (Table $1 \& 2$ ) indicated that all the characteristics were highly significant at 0.01 probability level. Such results were also presented by [12]. who created significantly differed attributes from one another. The genotypes were found significantly variable by [13]. for most of the characters too. Significant and variable outcomes were also gained by [14]. in mustard while doing their experiments.

\section{Mean performance}

Presence of genetic unpredictability is a precondition for the success of any breeding programme. Yield is the net resultant outcome of many variables that affect plant growth throughout the growing period. Main aim of any crop melioration program is to augment yield [15]. Mean 
performance results for ten genotypes in (Table $3 \& 4$ ) indicated that the genotype BJD BARD-1 discovered the least days to $75 \%$ flowering (47.42 days). The minimum days to $90 \%$ maturity were recorded in the genotype AARI Canola (120.20 days). In case of plant height, the shortest plants $(182.39 \mathrm{~cm})$ were detected by Super Raya. Furthermore, the maximum branches plant ${ }^{-}$ ${ }^{1}$ (9.46) were counted in the genotype AARI Canola. For pods plant $^{-1}$, the maximum pods plant ${ }^{-1}$ (482.57) were calculated by the genotype Super Raya. According to seeds pod $^{-1}$, the maximum seeds pod ${ }^{-1}$ (17.22) were counted by the genotype AARI Canola. The most seed yield plant $^{-1}$ was disclosed by the genotype Super Raya $(30.44 \mathrm{~g})$. In the results of seed index, the maximum values $(6.48 \mathrm{~g})$ for seed index were obtained by Dhoom-1. Finally, the most oil content $(39.28 \%)$ was disclosed by the genotype JS-13. These similar and variable results for mean performance were also articulated by previous scientists like [16]. who experimented with the genotypes of mustard and got the best results.

\section{Correlation}

The results of correlation in (Table 5) indicated that days to $75 \%$ flowering displayed highly significant and significant positive correlation with all traits except seed index which articulated nonsignificantly positive relationship with it. Days to $90 \%$ maturity revealed positive and highly significant including significant connections with many traits. On the contrary, non-significantly positive linkage of this trait was observed with pods plant ${ }^{-1}$. Such were in agreement with [17].

For plant height, positive and highly significant associations were reported with branches plant ${ }^{-1}$, pods plant ${ }^{-1}$ and oil content. On the other hand, it exposed positive, but significant correlations with pods per plant and seed yield per plant. The height of plant also articulated negative and non-significant relationship with seed index. There were observed highly significantly positive correlations of branches plant ${ }^{-1}$ with all the trait containing seed yield except for one in which it was non-significantly as well as negatively correlated with seed index. [18]. performed an experiment to find out the relationship between yield and yield linked traits in the genotypes of mustard.

Pods plant ${ }^{-1}$ only expressed positive highly significant relationships with seed yield plant $^{-1}$, seed index and oil content, while it was non-significant positively linked with only seeds pod $^{-1}$. Seeds pod ${ }^{-1}$ had significant as well as non-significant but positively related with seed yield plant $^{-1}$ and oil content. It also unveiled negative and non-significant association with seed index. Our results were in paradox with [19].

Seed yield plant $^{-1}$ disclosed only highly significant and positive connection with seed index and oil content. Seed index articulated positive and non-significant linkage with oil content. The trait which has positive correlation with seed yield is expected to influence genetic makeup of the genetic material in yield and attributes [20].

Table 1. Mean squares for different yield and yield contributing traits of mustard

\begin{tabular}{|c|c|c|c|c|c|c|}
\hline SOV & D. F. & $\begin{array}{c}\text { Days to } \\
\mathbf{7 5 \%} \\
\text { flowering }\end{array}$ & $\begin{array}{c}\text { Days to } \\
\mathbf{9 0 \%} \\
\text { maturity }\end{array}$ & $\begin{array}{c}\text { Plant } \\
\text { height } \\
\text { (cm) }\end{array}$ & $\begin{array}{c}\text { Branches } \\
\text { plant }^{-1}\end{array}$ & Pods plant $^{-}$ \\
\hline Replications & 2 & 0.035 & 0.192 & 0.01 & 0.135 & 0.02 \\
\hline Genotypes & 9 & $15.811^{* *}$ & $16.710^{* *}$ & $1456.27^{* *}$ & $7.389^{* *}$ & $2820.26^{* *}$ \\
\hline Error & 18 & 0.062 & 0.087 & 0.07 & 0.088 & 0.04 \\
\hline Total & 29 & - & - & - & - & - \\
\hline
\end{tabular}


Table 2. Mean squares for different yield and yield contributing traits of mustard

\begin{tabular}{|c|c|c|c|c|c|}
\hline SOV & D. F. & Seeds pod $^{\mathbf{1}}$ & $\begin{array}{c}\text { Seed yield } \\
\text { plant }^{-1}(\mathbf{g})\end{array}$ & $\begin{array}{c}\text { Seed index } \\
(\mathbf{g})\end{array}$ & $\begin{array}{c}\text { Oil content } \\
(\%)\end{array}$ \\
\hline Replications & 2 & 0.027 & 0.070 & 0.003 & 0.030 \\
\hline Genotypes & 9 & $8.680^{* *}$ & $29.145^{* *}$ & $4.798^{* *}$ & $9.208^{* *}$ \\
\hline Error & 18 & 0.117 & 0.074 & 0.079 & 0.068 \\
\hline Total & 29 & - & - & - & - \\
\hline
\end{tabular}

$* *$ = Highly significant at $\mathrm{P} \leq 0.01$ probability level

Table 3. Mean performance of yield and yield contributing traits in mustard genotypes

\begin{tabular}{|c|c|c|c|c|c|}
\hline Genotypes & $\begin{array}{c}\text { Days to } 75 \% \\
\text { flowering }\end{array}$ & $\begin{array}{c}\text { Days to } 90 \% \\
\text { maturity }\end{array}$ & $\begin{array}{l}\text { Plant height } \\
\text { (cm) }\end{array}$ & $\begin{array}{c}\text { Branches } \\
\text { plant }^{-1}\end{array}$ & $\begin{array}{l}\text { Pods } \\
\text { plant }^{-1}\end{array}$ \\
\hline AARI Canola & 49.25 & 120.20 & 194.37 & 9.46 & 400.20 \\
\hline JS-13 & 52.43 & 121.50 & 252.45 & 9.11 & 412.46 \\
\hline BJD BARD-1 & 47.42 & 126.27 & 235.49 & 8.50 & 415.36 \\
\hline BJD Khanpur Raya & 51.24 & 120.30 & 211.54 & 6.46 & 467.32 \\
\hline Early Raya & 52.18 & 125.40 & 217.42 & 7.36 & 450.32 \\
\hline $\operatorname{LSD}(5 \%)$ & 0.42 & 0.50 & 0.46 & 0.51 & 0.36 \\
\hline
\end{tabular}

Table 4. Mean performance of yield and yield contributing traits in mustard genotypes

\begin{tabular}{|c|c|c|c|c|}
\hline Genotypes & Seeds pod $^{-\mathbf{1}}$ & $\begin{array}{c}\text { Seed yield plant } \\
\mathbf{1}(\mathbf{g})\end{array}$ & Seed index (g) & Oil content (\%) \\
\hline Sindh Raya & 15.41 & 24.51 & 5.61 & 36.35 \\
\hline MS-4 & 14.36 & 25.72 & 5.37 & 35.53 \\
\hline Anmol Raya & 16.43 & 26.70 & 5.47 & 33.61 \\
\hline Dhoom-1 & 14.46 & 28.42 & 6.48 & 34.40 \\
\hline Super Raya & 14.26 & 30.44 & 6.27 & 36.63 \\
\hline LSD (5\%) & $\mathbf{0 . 5 8}$ & $\mathbf{0 . 4 6}$ & $\mathbf{0 . 4 8}$ & $\mathbf{0 . 4 4}$ \\
\hline
\end{tabular}


Table 5. Correlation of coefficient ( $r$ ) among yield and yield related traits in mustard genotypes

\begin{tabular}{|c|c|c|c|c|c|c|c|c|}
\hline Traits & $\begin{array}{c}\text { Days to } 75 \% \\
\text { flowering }\end{array}$ & $\begin{array}{c}\text { Days to } 90 \% \\
\text { maturity }\end{array}$ & $\begin{array}{l}\text { Plant height } \\
\text { (cm) }\end{array}$ & $\begin{array}{c}\text { Branches } \\
\text { plant }^{-1}\end{array}$ & Pods plant $^{-1}$ & Seeds pod ${ }^{-1}$ & $\begin{array}{l}\text { Seed yield } \\
\text { plant }^{-1}(\mathrm{~g})\end{array}$ & $\begin{array}{c}\text { Seed index } \\
\text { (g) }\end{array}$ \\
\hline Days to $90 \%$ maturity & $0.8821 * *$ & & & & & & & \\
\hline Plant height (cm) & $0.8167 * *$ & $0.7123^{* *}$ & & & & & & \\
\hline Branches plant $^{-1}$ & $0.4571^{*}$ & $0.3697 *$ & $0.5898 * *$ & & & & & \\
\hline Pods plant ${ }^{-1}$ & $0.8157 * *$ & $0.8959 * *$ & $0.6453^{* *}$ & $0.4791 * *$ & & & & \\
\hline Seeds pod ${ }^{-1}$ & $0.3531 *$ & $0.2683^{\mathrm{NS}}$ & $0.4105^{*}$ & $0.6662 * *$ & $0.1933^{\mathrm{NS}}$ & & & \\
\hline Seed yield plant $^{-1}(\mathrm{~g})$ & $0.6556^{* *}$ & $0.7271 * *$ & $0.4562 *$ & $0.4762 * *$ & $0.8498 * *$ & $0.3433 *$ & & \\
\hline Seed index (g) & $0.1249^{\mathrm{NS}}$ & $0.4860 * *$ & $-0.0792^{\mathrm{NS}}$ & $-0.0808^{\mathrm{NS}}$ & $0.5706 * *$ & $-0.2280^{\mathrm{NS}}$ & $0.5319^{* *}$ & \\
\hline Oil content $(\%)$ & $0.8737 * *$ & $0.8903^{* *}$ & $0.8244 * *$ & $0.4392 *$ & $0.7755^{* *}$ & $0.2557^{\mathrm{NS}}$ & $0.5422 * *$ & $0.1815^{\mathrm{NS}}$ \\
\hline
\end{tabular}

** = Highly significant at $\mathrm{P} \leq 0.01$ probability level, $*=$ Significant at $\mathrm{P} \leq 0.05$ probability level, NS $=$ Non-significant at $\mathrm{P} \geq 0.05$ probability level 


\section{Conclusion}

All genotypes were highly significant at 0.01 level of probability for all the studied attributes. The genotypes like BJD BARD1, AARI Canola, Super Raya, Dhoom-1 and JS-13 performed brilliantly. Positive and highly significant and significant association of seed yield plant ${ }^{-1}$ with all the characteristics. It was concluded that selection of these attributes demonstrating significant and marvellous results would be very fruitful and progressive for desirable genes. The better performed mustard genotypes will be able to be utilized in future for mustard development programmes to improve yield associated characters.

\section{Authors' contributions}

Conceived and designed the experiments: PA Shar \& JK Sootaher, Performed the experiments: PA Shar, TF Abro \& MS Chang, Analyzed the data: ZA Soomro \& KH Rind, Contributed materials/ analysis/ tools: AH Shar \& NA Rind, Wrote the paper: JK Sootaher.

\section{References}

1. Lyngdoh $Y$, Kanaujia SP \& Shah P (2017). Genetic variability, characters association and path coefficient analysis in green mustard (Brassica juncea L.) genotypes. Int Rec Sci Res 8(8): 19388-19391.

2. Maurya JK, Singh AK, Singh A, Singh DR, Singh PK \& Om S (2019). Studies on character association and path analysis of vigour and vigour contributing traits in Indian mustard (Brassica juncea L.) germplasm. Int J Chem Studies 7(3): 4708-4712.

3. Mustafa HSB, Mahmood T, Ejaz ul Hasan, Hassan M, Hameed A, Saddique F \& Tayyab M (2017). Seed yield evaluation and association between yield components in different advanced lines of mustard (Brassica juncea L.). Specialty J Agric Sci 3(2): 8-13.
4. Mahmood T, Hussain M, Mustafa HSB, Hasan E \& Aftab M (2017). Aari Canola: Pakistan's first ever canola quality and short duration Mustard (Brassica juncea L.) cultivar resilient to climate change. Int J Biol Pharm Al Sci 6(4): 777787.

5. Ompal SA, Kerkhi, Chand P, Singh SK \& Yadav MK (2018). Study of correlation and path coefficient analysis in Indian mustard (Brassica juncea L.). J Pharmaco Phytochem 7(6): 890-894.

6. Rauf MA \& Rahim MA. 2018. Genetic variability studies among yield and its contributing traits in mustard (Brassica napus L.). Adv Zool Bot 6(4): 101-108.

7. Dawar S, Kumar \& Mishra SP (2018). Genetic variability, correlation and path coefficient analysis in the Indian mustard (Brassica juncea L.) varieties grown in Chitrakoot. Int J Curr Microbiol App Sci 7(03): 883-890.

8. Jan SA, Shinwari ZK \& Rabbani MA (2016). Morphobiochemical evaluation of $\mathrm{B}$. rapa sub-species for salt tolerance. Genet 8: 323-338

9. Gomez KA \& Gomez AA (1984). Statistical procedures in agricultural Research. Wiley, $2^{\text {nd }}$ ed. New York.

10. Steel RGD \& Torrie JH (1960). Principles and procedures of statistics.

11. Snedecor GW \& Cochran WG (1980). Statistical Methods, 7th edition. Iowa State University Press, Ames, Iowa.

12. Muhammad MUH, Muhammad NI, Kadir M \& Miah NH (2016). Performance of rapeseed and mustard varieties/lines in north-east region of Bangladesh. Adv Plants Agric Res 5(1): 457-462.

13. Swetha M, Janeja HS, Singh H, Sravani M, Rajaneesh K \& Madakemohekar AH (2019). Genetic evaluation of Indian 
mustard (Brassica juncea L.) genotypes for yield and quality parameters. Plant Archives 19(1): 413-417.

14. Tiwari VK (2019). Morphological parameters in breeding for higher seed yield in Indian mustard (Brassica juncea L.). Elect J Plant Breed 10(1): 187-195.

15. Singh B, Supriya R, Sukhdeep S \& Mishra P (2019). Study of correlation and path analysisin Indian mustard (Brassica juncea L.). Int Arch App Sci Technol 10(1): 33-37.

16. Raliya B, Kumar K, Ramesh, Pukhraj, Rakesh J, Meena \& Mundiyara R (2018). Genetic variability and character association in Indian mustard (Brassica juncea L.). Int J Agric Sci 10(9): 59935996.

17. Tripathi A, Singh M \& Tomar A (2019). Selection parameter analysis in Indian mustard (Brassica juncea L.) germplasm under normal sown condition. $J$ Pharmaco Phytochem 8(1): 15511553.

18. Prasad G \& Patil BR (2018). Association and path coefficient analysis in Indian mustard genotypes. Int J Chem Stu 6(5): 362-368.

19. Kumar A, M. Singh, R. K. Yadav, P. Singh and Lallu (2018). Study of correlation and path coefficient among the characters of Indian mustard. Pharma Innov J 7(1): 412416.

20. Kumar R, Kaur S, Bala K, Kaur S \& Sharma L (2019). Assessment of genetic variability, correlation and path analysis for yield traits in $F_{1}$ hybrids of Indian mustard (Brassica juncea L.). Agriways 7(1): 1-7. 